\title{
Sexual and age differences in ecological variables of the lizard Microlophus atacamensis (Tropiduridae) from northern Chile
}

\author{
Diferencias sexuales y etárias en variables ecológicas del lagarto Microlophus \\ atacamensis (Tropiduridae) del norte de Chile
}

\author{
MARCELA VIDAL ${ }^{1}$, JUAN C. ORTIZ ${ }^{1} \&$ ANTONIETA LABRA ${ }^{2}$
}

\author{
${ }^{1}$ Departamento de Zoología, Facultad de Ciencias Naturales y Oceanográficas, Universidad de \\ Concepción, Casilla 160-C, Concepción, Chile \\ ${ }^{2}$ Departamento de Ecología, Facultad de Ciencias Biológicas, Pontificia Universidad Católica de Chile, \\ Casilla 114-D, Santiago 6513677, Chile
}

\begin{abstract}
Microlophus is a lizard genus of South-America which has many species with sexual size dimorphism. An ecological study was performed on M. atacamensis, a species inhabiting the intertidal zone of the coast of northern Chile. The following questions were addressed: (1) does M. atacamensis exhibit sexual dimorphism? (2) do individuals of different age and sex segregate spatially? (3) do individuals of different age and sex use different type of microhabitat? and (4) do individuals of different sexes exhibit differences in thermoregulatory characteristics? The study was conducted in different localities from northern Chile, which include two types of rocky systems used by this species, a high and a low type. At the moment of lizard capture, type of microhabitat, height of perch, body, air and substrate temperatures, were recorded. Individuals were then measured and weighted, and separated by age class and sex. Results indicate that this species exhibits sexual dimorphism, males being larger. There were no intersexual differences in microhabitat used and height of perch in the high type system, although adults and subadults were spatially segregated from juveniles. In the low type system adult females shared microhabitat with juveniles, a probable consequence of behaviors related to the burying of eggs. There were no differences between sexes in thermal characteristics, and body temperature of lizards showed independence from external thermal conditions.
\end{abstract}

Key words: Tropiduridae, Microlophus atacamensis, sexual dimorphism, thermoregulation, spatial segregation, Chile.

\section{RESUMEN}

Microlophus es un género de lagartos Sudamericanos, el cual tiene varias especies que presentan dimorfismo sexual del tamaño. Se realizó un estudio ecológico en Microlophus atacamensis, especie del intermareal de la costa del norte de Chile, para responder a las siguientes preguntas: (1) ¿presenta M. atacamensis dimorfismo sexual? (2) ¿existe segregación espacial entre individuos de diferentes edades y sexos? (3) ¿existe utilización diferencial de los tipos de hábitats, entre individuos de diferentes edades y sexos? y (4) ¿existen diferencias intersexuales en las características termorregulatorias? El estudio se realizó en diferentes localidades del norte de Chile, que incluyen dos tipos de sistemas rocosos utilizados por esta especie, alto y bajo. Los individuos fueron medidos, pesados, y al momento de su captura se determinó el tipo de microhabitat y altura de la percha utilizada; se registro la temperatura del cuerpo, aire y del substrato. Los individuos fueron separados por clases etárias y sexo. Los resultados indican que esta especie presenta dimorfismo sexual, siendo los machos más grandes que las hembras. No hubo diferencias intersexuales en el uso de los microhabitats ni en la altura de la percha en el sistema rocoso alto, aunque los adultos y subadultos están segregados espacialmente de los infantiles. Las hembras adultas comparten el microhabitat con los infantiles en el sistema rocoso bajo, esto, probablemente consecuencia de las conductas asociadas a la postura de huevos. No se registraron diferencias intersexuales en las características térmicas y los individuos mostraron una independencia frente a las condiciones térmicas externas.

Palabras clave: Tropiduridae, Microlophus atacamensis, dimorfismo sexual, termorregulación, segregación espacial, Chile.

\section{INTRODUCTION}

In most animal groups, sexual differences in morphological characters (sexual dimorphism), particularly in body size, is a common phenomenon. The direction of this difference, i.e., whether males or females are bigger, differs between animals groups; in vertebrates males typically constitute the larger sex (Schoener et al. 1982, Shine 1986, Fairbairn 1990, 1997, Andersson 1994). Several proximate mechanisms have been proposed to explain sexual dimor- 
phism, such as differential mortality of sexes (Stamps 1993) and different growth rates of sexes (Watkins 1996). However, natural or sexual selection remain the ultimate mechanisms explaining sexual dimorphism (Shine 1986, Andersson 1994, Watkins 1998).

Many species of the lizard genus Microlophus show sexual dimorphism (Dixon \& Wright 1975 , Ortiz 1980a, Snell et al. 1988, Watkins 1994, 1996, 1997, 1998). In the case of M. occipitalis the mechanism determining this dimorphism is the differential growth rates of sexes (Watkins 1996). Six species of Microlophus live in Chile (Ortiz 1980a), most of them associated to intertidal zones (Donoso-Barros 1966). Microlophus atacamensis inhabits from Antofagasta (23\%39' $\left.\mathrm{S}, 7^{\circ} 24^{\prime} \mathrm{W}\right)$ to Huasco $\left(28^{\circ} 28^{\prime} \mathrm{S}, 71^{\circ} 14^{\prime} \mathrm{W}\right)$ (Ortiz 1980b) ${ }^{1}$, and feeds on algae, crustaceans, mollusks and insects in the intertidal zone (Donoso-Barros 1948, 1966, Heisig 1993). Previous studies suggest that $M$. atacamensis shows sexual size dimorphism and that individuals might spatially segregate by age class and sex (DonosoBarros 1966, Flores et al. 1977, Ortiz 1980a, Heisig 1993); males use microhabitats with higher availability of sunny perches and closer to food resources, than do females (Heisig 1993). Given that in the intertidal zone where M. atacamensis is found (Donoso-Barros 1948, 1966, Heisig 1993), is a low temperature microhabitat (Báez \& Cortés 1990), the sexual spatial segregation may be reflected in differences in thermoregulatory strategy. To clarify if previous suggestions on some ecological characteristics of $M$. atacamensis (Donoso-Barros 1966, Flores et al. 1977, Ortiz 1980a, Heisig 1993) have support, we addressed the following questions: (1) does M. atacamensis have sexual dimorphism? (2) do individuals of different age and sex segregate spatially? (3) do individuals of different age and sex use different types of microhabitats? and (4) do individuals of different sex exhibit differences in thermoregulatory characteristics?

\section{MATERIAL AND METHODS}

The study was performed during April and December 2000, in eight intertidal localities of the north of Chile located between the Loa river ( $21^{\circ} 26^{\prime} \mathrm{S}, 70^{\circ} 04^{\prime} \mathrm{W}$ ) and Tres Playitas (28 $28^{\prime} \mathrm{S}$, $\left.71^{\circ} 14^{\prime} \mathrm{W}\right)$. These localities are situated in areas with coastal desert and perarid Mediterranean climatic characteristics, respectively (Di Castri 1968).

Sites were continuously walked along parallel $30 \mathrm{~m}$ transect lines (perpendicular to the coastal line), during the whole daily active period of lizards, in both months (09:45 to 18:30 h). Transects were walked in opposite directions to minimize the probability of repeatedly observing the same individual. Two types of rocky systems can be distinguished in the habitat of $M$. atacamensis: (a) high type system, characterized by the presence of rocks with heights from 0.20 to $3 \mathrm{~m}$, in contact with the sea, behind which there is sand with boulders with heights from 0.10 to 0.20 $\mathrm{m}$; (b) low type system, consisting of a stripe of boulders with heights from 0.20 to $0.35 \mathrm{~m}$, in contact with the sea, behind which there is sand (Fig. 1).

For each lizard observed, the type of substrate used (rocks, boulders or sand) and its height (m) were recorded. A total of 86 individuals were collected (high type system $\mathrm{n}=54$, low type system $\mathrm{n}=32$ ). Immediately after capturing a lizard, the following temperatures were recorded: body (cloacal, $\left.\mathrm{T}_{\mathrm{b}}\right)$, air (10 $\mathrm{cm}$ above the substrate, $\mathrm{T}_{\mathrm{a}}$ ), and substrate (in contact with the surface, $\mathrm{T}_{\mathrm{s}}$ ), with a UNI-T M-890C thermometer $\left( \pm 0.1{ }^{\circ} \mathrm{C}\right)$. Lizards were weighed $(\mathrm{g})$ and measured $(\mathrm{mm})$; some individuals were sacrificed, fixed in $70 \%$ alcohol, labeled, and donated to the herpetologi-

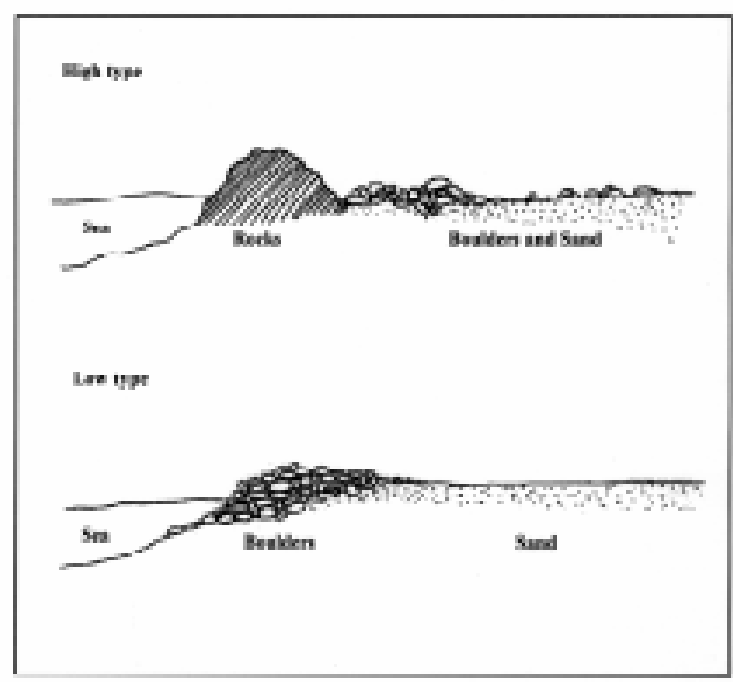

Fig. 1: Substrates used by M. atacamensis; high and low systems.

Sustratos utilizados por Microlophus atacamensis; sistemas alto y bajo.

${ }^{1}$ ORTIZ JC (1980b) Revisión taxonómica del género 
cal collection of the Museo de Zoología of Universidad de Concepción (MZUC, see Appendix 1). The morphological measurements obtained from each animal were: snout-vent length (SVL), head length (HL), head width (HW), and right hindlimb length (RHL), with a Mitutoyo caliper $( \pm 0.01 \mathrm{~mm})$. Thereafter, and following Flores et al. (1977) and Ortiz (1980b), lizards were classified as adults, subadults or juveniles, according to body size (SVL).

The sexual dimorphism index (SDI) was calculated for adults and subadults (Lovich et al. 1990, Lovich \& Gibbons 1992, Watkins 1996), where:

$$
\begin{aligned}
\mathrm{SDI}= & (\text { mean body size of the larger sex / mean } \\
& \text { body size of the smaller sex })-1
\end{aligned}
$$

Results were defined as positive when males were larger than females.

Since the final sample size per locality was small, data were pooled. Analyses of the differences between sexes and ages in SVL, weight, microhabitat use, and perch height, were performed by two-way analysis of variance (ANOVA), followed by Tukey tests (Zar 1996). Comparisons of HL, HW and RHL between sexes were performed using analysis of covariance (ANCOVA), with SVL as covariate (Sokal \& Rohlf 1981); data were previously normalized using $\log _{10}$. A one-way ANOVA was used to determine differences between sexes in cloacal temperature in relation to air and substrate temperatures. The thermoregulatory ability was estimated from the variances of $\mathrm{T}_{\mathrm{b}}$, and from the slopes of the linear regressions (Sokal \& Rohlf 1981, Dytham 1999) between $\mathrm{T}_{\mathrm{b}}$ and $\mathrm{T}_{\mathrm{a}}$ and between $\mathrm{T}_{\mathrm{b}}$ and $\mathrm{T}_{\mathrm{s}}$ (Huey 1982, Pérez-Mellado \& de la Riva 1993). A slope equal to one indicates that animals are completely thermodependent (Báez \& Cortés 1990).

\section{RESULTS}

The morphometric measurements obtained for the different age classes (excluding juveniles) and sexes are shown in Table 1. A two-way ANOVA, considering age and sex as factors on SVL, indicated that males were significantly longer than females $\left(\mathrm{F}_{1,56}=30.81, \mathrm{P}=0.001\right)$. Significant differences in SVL were observed between adults and subadults $\left(\mathrm{F}_{1,56}=59.23, \mathrm{P}=\right.$ 0.001). The interaction of both factors was not significant $\left(\mathrm{F}_{1,56}=2.49, \mathrm{P}=0.12\right)$, although the dimorphism index in adults $(\mathrm{SDI}=0.18)$ was higher than in subadults (SDI $=0.12$ ). There were significant differences in weight between sexes $\left(\mathrm{F}_{1,56}=14.53, \mathrm{P}=0.001\right)$, males being heavier than females. There were differences in weight between age classes $\left(\mathrm{F}_{1,56}=59.19, \mathrm{P}=0.001\right)$, although the interaction between factors was not significant $\left(\mathrm{F}_{1,56}=3.18, \mathrm{P}=0.08\right)$.

Males had longer hindlimbs and heads, and wider heads than females, either at the adult or subadults stage (Table 1 and 2). HL and WH, but not RHL, of males and females correlated positively with SVL (Table 2, Fig. 2). However, the interaction with the covariate does not show a difference of slopes for HL and HW, but it does for RHL (Table 3).

Table 4 shows the use of microhabitat by different age classes and sexes, in both rocky systems. A two-way ANOVA considering age and sex as factors, indicated that only age affected the substrate used, in the high system $\left(\mathrm{F}_{2,48}=44.60, \mathrm{P}=\right.$ 0.001 ); juveniles were observed only in the sand,

\section{TABLE 1}

Morphometry of adults and subadults of Microlophus atacamensis. Data are mean \pm standard deviation $(\mathrm{mm})$. Key to abbreviations: $\mathrm{n}=$ sample size, $\mathrm{SVL}=$ snout-vent length, $\mathrm{HL}=$ head length, HW = head width, and RHL = right hindlimb length

Morfometría de adultos y subadultos de Microlophus atacamensis. Los datos se presentan como promedio \pm desviación estándar $(\mathrm{mm})$. Clave de abreviaciones: $\mathrm{n}=$ tamaño de la muestra, SVL = longitud hocico-cloaca, HL = longitud de la cabeza, HW = ancho de la cabeza, y RHL = longitud de la extremidad posterior derecha

\begin{tabular}{lccccc}
\hline Group & $\mathrm{n}$ & SVL & HL & HW & RHL \\
\hline Adult males & 12 & $114.10 \pm 12.9$ & $24.34 \pm 2.2$ & $19.59 \pm 2.5$ & $82.97 \pm 8.8$ \\
Adult females & 12 & $96.06 \pm 6.8$ & $20.26 \pm 1.3$ & $15.74 \pm 1.4$ & $72.25 \pm 6.1$ \\
Subadult males & 13 & $90.63 \pm 4.6$ & $20.61 \pm 2.9$ & $15.43 \pm 1.1$ & $73.50 \pm 4.8$ \\
Subadult females & 24 & $80.57 \pm 9.5$ & $17.34 \pm 1.8$ & $13.31 \pm 1.4$ & $62.93 \pm 9.2$ \\
\hline
\end{tabular}


TABLE 2

Three covariance analyses for head length (HL), head width (HW), and right hindlimb length (RHL), using snout-vent length (SVL) as covariate and sex as factor. Data came from adults and subadults of Microlophus atacamensis

Tres análisis de covarianza para la longitud de la cabeza (HL), ancho de la cabeza (HW) y la longitud de la extremidad posterior derecha (RHL), utilizando la longitud hocico-cloaca (SVL) como covariable y el sexo como el factor. Los datos son de adultos y subadultos de Microlophus atacamensis

\begin{tabular}{|c|c|c|c|c|c|}
\hline Variable & Source of variation & $\begin{array}{l}\text { Degrees of } \\
\text { freedom }\end{array}$ & Mean square & F-value & P-value \\
\hline HL & $\begin{array}{c}\text { Between sexes } \\
\text { Error }\end{array}$ & $\begin{array}{c}1 \\
54\end{array}$ & $\begin{array}{l}0.006 \\
0.006\end{array}$ & 9.58 & 0.003 \\
\hline HW & $\begin{array}{c}\text { Between sexes } \\
\text { Error }\end{array}$ & $\begin{array}{c}1 \\
54\end{array}$ & $\begin{array}{l}0.002 \\
0.004\end{array}$ & 6.4 & 0.010 \\
\hline RHL & $\begin{array}{c}\text { Between sexes } \\
\text { Error }\end{array}$ & $\begin{array}{c}1 \\
54\end{array}$ & $\begin{array}{l}0.002 \\
0.009\end{array}$ & 3.14 & 0.080 \\
\hline
\end{tabular}

while adults and subadults of both sexes basically did not use this substrate $(\mathrm{P}<0.001)$. Table 5 shows the height of the perch used by the five agesex classes defined. A two-way ANOVA indicated that only age in the high system, had an effect on the height of the perch; juveniles used significantly lower perches than the other categories $(\mathrm{P}<0.01)$. In the low system, the significance of the effect of age was marginal $\left(\mathrm{F}_{2,25}=3.00, \mathrm{P}=\right.$ $0.068)$, because perches of similar height were used by juveniles and females $(P=0.095)$.

The mean body temperature of $M$. atacamensis was $24{ }^{\circ} \mathrm{C}$, and sexes had similar temperatures $\left(\mathrm{F}_{1,60}=0.18, \mathrm{P}=0.65\right)$. Body temperature showed similar ranges and standard deviations in both sexes (Table 6). There were no significant differences between males and females in the relationships $\mathrm{T}_{\mathrm{b}}$ versus $\mathrm{T}_{\mathrm{a}}\left(\mathrm{F}_{1,60}=2.84, \mathrm{P}=0.09\right)$ and $\mathrm{T}_{\mathrm{b}}$ versus $T_{s}\left(F_{1,60}=1.37, P=0.24\right)$. The slopes of the regressions of $T_{b}$ versus $T_{a}$ and $T_{b}$ versus $T_{s}$, were not different from zero, in both sexes (Fig. 3).

\section{DISCUSSION}

Results indicate that $M$. atacamensis exhibit sexual size dimorphism. The snout-vent length, the length of hindlimb and head, and the width of the head, were larger in males. The existence of species with sexual dimorphism has been documented in many lizard families, such as Tropiduridae (Schoener et al. 1982, Pérez-Mellado \& de la Riva 1993, Duarte 1996) and Iguanidae (Schoener 1967, Cooper \& Vitt 1989, Anderson \& Vitt 1990). The fact that Microlophus and species of other genus of the family Tropiduridae show sexual

TABLE 3

Test of parallelism of interaction of the factor (sex) with the covariate (SVL) for head length (HL), head width (HW), and right hindlimb length (RHL). Data came from adults and subadults of Microlophus atacamensis

Prueba de Paralelismo de interacción del factor (sexo) con la covariable(SVL) para la longitud de la cabeza (HL), ancho de la cabeza (HW) y la longitud de la extremidad posterior derecha (RHL). Los datos son de adultos y subadultos de Microlophus atacamensis

\begin{tabular}{lccccc}
\hline Variable & Source of variation & $\begin{array}{c}\text { Degrees } \\
\text { of freedom }\end{array}$ & Mean square & F-value & P-value \\
\hline $\mathrm{HL}$ & Between sexes & 1 & 0.0002 & 0.33 & 0.566 \\
$\mathrm{HW}$ & Error & 54 & 0.0006 & & 0.138 \\
& Between sexes & 1 & 0.0011 & 2.26 & 0.049 \\
$\mathrm{RHL}$ & Error & 54 & 0.0005 & & 4.04 \\
& Between sexes & 1 & 0.0030 & &
\end{tabular}


(A)

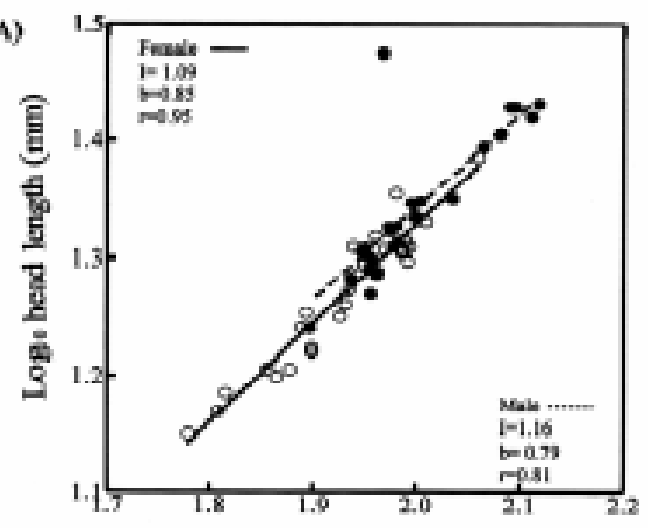

(B)

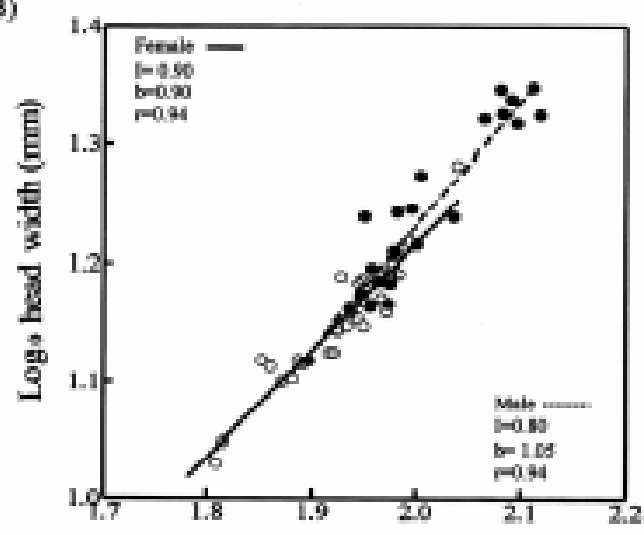

Logio snout-vent length (mm)

(C)

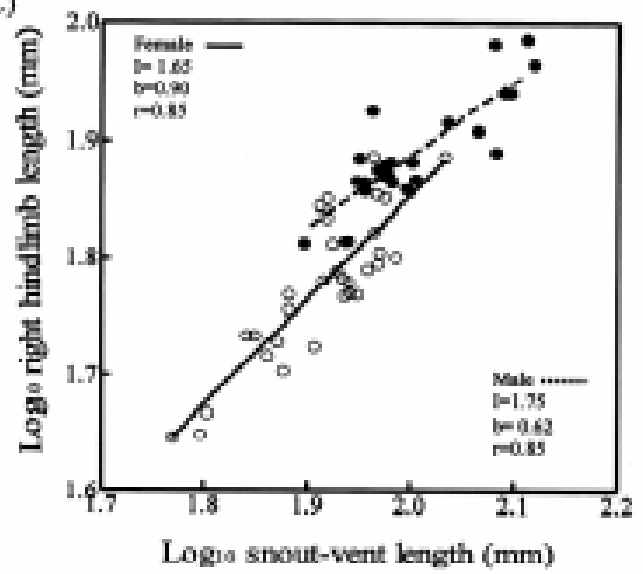

Fig. 2: Relationship between snout-vent length and (A) head length, (B) head width, (C) right hindlimb length in $(\cdots)$ males and $(-)$ females of Microlophus atacamensis. The intercept (I) and slope (b) values of the linear regression are indicated. Values of ANCOVA are in Table 2.

Relación entre la longitud hocico-cloaca y (A) largo de la cabeza, (B) ancho de la cabeza, (C) longitud de la extremidad posterior derecha en ( $\cdots)$ machos y $(-)$ hembras de Microlophus atacamensis. Se indican los valores del intercepto (I) y la pendiente (b) de cada regresión lineal. Los valores de ANCOVA están en la Tabla 2. size dimorphism (Schoener et al. 1982, Snell et al. 1988, Pérez-Mellado \& de la Riva 1993, Duarte 1996, Watkins 1996, 1998), strongly suggests that this character may be ancestral in the family. In Microlophus the degree of sexual dimorphism shows intrageneric variation, and $M$. atacamensis is one of the species with the smallest dimorphism indexes, even if only the values obtained for adults are considered (Watkins 1996). This suggests that the selective pressures that maintain

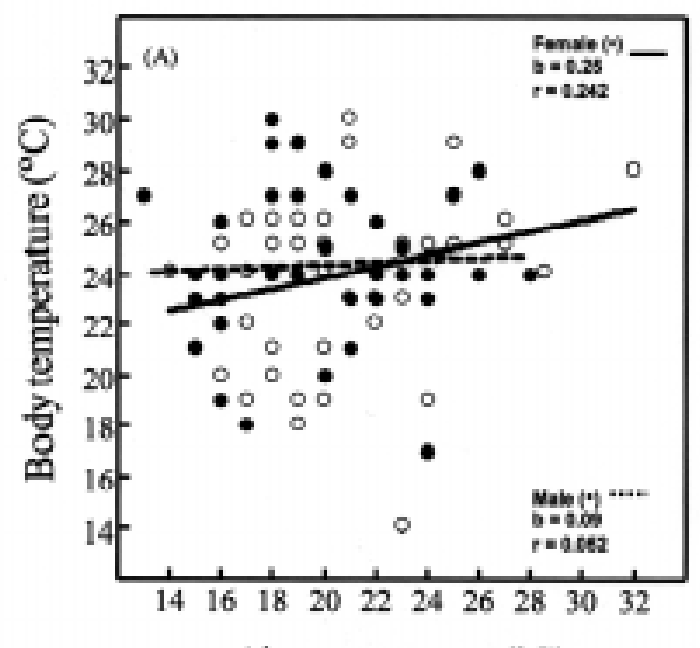

Air temperature $\left({ }^{\circ} \mathrm{C}\right)$

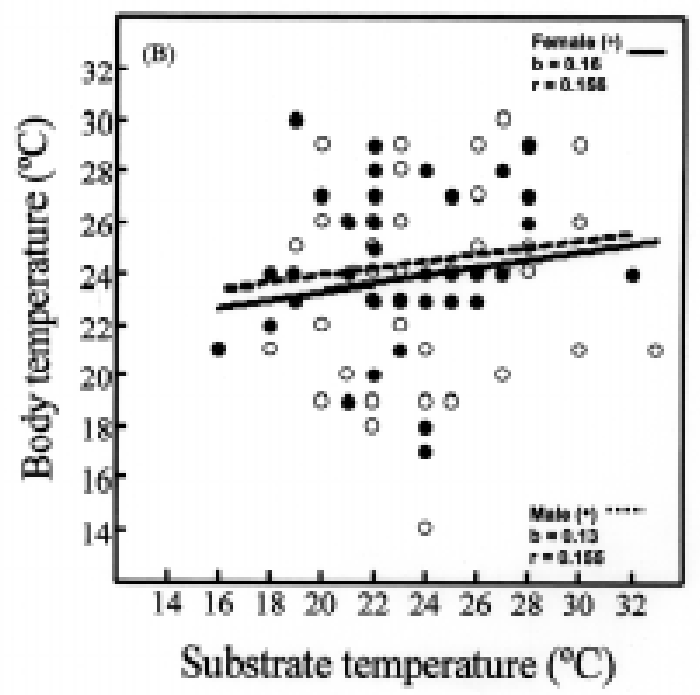

Fig. 3: Relationship between (A) body and air temperature $\left(\mathrm{T}_{\mathrm{b}}-\mathrm{T}_{\mathrm{a}}\right)$ and $(\mathrm{B})$ body and substrate temperatures $\left(\mathrm{T}_{\mathrm{b}}-\mathrm{T}_{\mathrm{s}}\right)$ in $(\cdots)$ males and $(-)$ females of Microlophus atacamensis. The slopes of regression (b) and $\mathrm{r}$ values are indicated.

Relación entre (A) temperatura corporal y ambiental ( $\mathrm{T}_{\mathrm{b}}$ $\mathrm{T}_{\mathrm{a}}$ ) y (B) temperatura corporal y del sustrato $\left(\mathrm{T}_{\mathrm{b}}-\mathrm{T}_{\mathrm{s}}\right)$ en $(\cdots)$ machos y (-) hembras de Microlophus atacamensis. Se indica el valor de la pendiente de la ecuación de regresión (b) y su respectivo valor de $r$. 
TABLE 4

Microhabitats used (\%) by Microlophus atacamensis in two rocky systems, high and low type; $\mathrm{n}=$ sample size

Microhabitats utilizados (\%) por Microlophus atacamensis en dos sistemas rocosos, alto y bajo; $\mathrm{n}=$ tamaño de la muestra

\begin{tabular}{lcccccc}
\hline Group & \multicolumn{2}{c}{ High type } & \multicolumn{2}{c}{ Low type } \\
& $\mathrm{n}$ & Rocks & Boulders & $\mathrm{n}$ & Boulders & Sand \\
\hline Adult males & 6 & 100 & 0 & 6 & 100 & 0 \\
Adult females & 10 & 100 & 0 & 3 & 67 & 33 \\
Subadult males & 6 & 100 & 0 & 7 & 71 & 29 \\
Subadult females & 12 & 92 & 8 & 11 & 55 & 45 \\
Juveniles & 20 & 20 & 80 & 5 & 0 & 100 \\
\hline
\end{tabular}

sexual dimorphism in M. atacamensis are weaker than for other Microlophus species. Additionally, the differences in SDI observed between adults and subadults of $M$. atacamensis, suggests that the proximal mechanism of this sexual size dimorphism is a differential growth rate between sexes, as was proposed for M. occipitalis (Watkins 1996).

The ultimate mechanisms proposed to explain sexual dimorphism are natural and sexual selection (Darwin 1871), and the degree of elaboration of a trait would be determined by a balance between the costs and benefits associated with these two mechanisms (Shine 1989, Pérez-Mellado \& de la Riva 1993). Natural selection involves an ecological segregation of sexes in at least one niche axes, in which resources are limited, thus reducing intraspecific competition. Dietary niche partitioning between sexes has been discussed as a possible selective force underlying evolution of sexual size dimorphism in lizards, in cases where food resources are limited (Shine 1986, Camilleri \& Shine 1990, Fairbain 1990, Andersson 1994).
Because head size is related to the size of prey consumed (Schoener 1967, Schoener et al. 1982), morphometric results of M. atacamensis may support the hypothesis of trophic segregation between sexes. To date, there is no information about the nature and availability of the prey consumed by this species, or whether sexes consume different prey.

On the other hand, sexual selection proposes that females select larger males given the strong relationship between body size and competitive efficiency, which leads to larger males having larger or higher quality territories (Manzur \& Fuentes 1979, Heisig 1993). Moreover, males with larger head show higher success during intrasexual agonistic interactions (Cooper \& Vitt 1989, Anderson \& Vitt 1990, Watkins 1998). Considering that $M$. atacamensis has a polygynic social system (Heisig 1993), sexual selection seems to be the most likely hypothesis to explain sexual dimorphism in this species (Martins 1994).

The sexual size dimorphism observed in adults and subadults of M. atacamensis, was not corre-

TABLE 5

Perch height $(\mathrm{m})$ used by the different age classes and sexes of Microlophus atacamensis in two rocky systems, high and low type. Data are given as mean \pm standard deviation (mean \pm $\mathrm{SD})$ and range $(\mathrm{R}) ; \mathrm{n}=$ sample size

Altura de la percha (m) utilizadas por las diferentes clases etárias y de sexos de Microlophus atacamensis en dos sistemas rocosos, alto y bajo. Los datos corresponden a medias \pm desviación estándar (mean $\pm \mathrm{SD})$ y rangos $(\mathrm{R})$; $\mathrm{n}=$ tamaño de muestra

\begin{tabular}{lccrrrr}
\hline Group & \multicolumn{3}{c}{ High type } & \multicolumn{3}{c}{ Low type } \\
& $\mathrm{n}$ & Mean $\pm \mathrm{SD}$ & $\mathrm{R}$ & $\mathrm{n}$ & Mean $\pm \mathrm{SD}$ & $\mathrm{R}$ \\
\hline Adult males & 6 & $2.0 \pm 1.04$ & $1.0-3.5$ & 6 & $0.10 \pm 0.04$ & $0.10-0.20$ \\
Adult females & 10 & $2.1 \pm 1.01$ & $1.0-3.5$ & 3 & $0.06 \pm 0.06$ & $0.00-0.12$ \\
Subadult males & 6 & $2.3 \pm 0.98$ & $1.5-4.0$ & 7 & $0.09 \pm 0.03$ & $0.04-0.12$ \\
Subadult females & 12 & $1.7 \pm 0.66$ & $0.5-2.5$ & 11 & $0.08 \pm 0.04$ & $0.00-0.12$ \\
Juveniles & 20 & $0.3 \pm 0.63$ & $0.0-2.5$ & 5 & $0.04 \pm 0.04$ & $0.00-0.08$ \\
\hline
\end{tabular}


Temperature values (mean \pm standard deviation, interquartil range, and in parenthesis the temperature ranges) measured for adults, subadults and juveniles of both sexes of Microlophus atacamensis. Key to abbreviations: $\mathrm{T}_{\mathrm{b}}=$ body temperature, $\mathrm{T}_{\mathrm{a}}=$ air temperature, $\mathrm{T}_{\mathrm{S}}=$ substrate temperature, $\mathrm{n}=$ sample size

Temperaturas (promedio \pm desviación estándar, rango intercuartil, y rangos de temperaturas en paréntesis) medidas en adultos, subadultos e infantiles de ambos sexos de Microlophus atacamensis. Clave de abreviaciones: $\mathrm{T}_{\mathrm{b}}=$ temperatura cloacal, $\mathrm{T}_{\mathrm{a}}=$ temperatura ambiental, $\mathrm{T}_{\mathrm{S}}=$ temperatura del substrato, $\mathrm{n}=$ tamaño de la muestra

\begin{tabular}{|c|c|c|c|c|}
\hline Sex & $\mathrm{T}_{\mathrm{b}}$ & $\mathrm{T}_{\mathrm{a}}$ & $\mathrm{T}_{\mathrm{s}}$ & $\mathrm{n}$ \\
\hline Males & $\begin{array}{c}24.35 \pm 2.9 \\
4.0 \\
(17-30)\end{array}$ & $\begin{array}{c}19.85 \pm 3.6 \\
6.0 \\
(13-28)\end{array}$ & $\begin{array}{c}23.60 \pm 3.6 \\
4.0 \\
(16-32)\end{array}$ & 40 \\
\hline Females & $\begin{array}{c}24.15 \pm 3.3 \\
5.0 \\
(18-30)\end{array}$ & $\begin{array}{c}20.70 \pm 3.7 \\
5.0 \\
(15-32)\end{array}$ & $\begin{array}{c}23.77 \pm 3.8 \\
4.0 \\
(16-33)\end{array}$ & 46 \\
\hline
\end{tabular}

lated with a differential use of substrate. This result is interesting because different studies indicate a strong relationship between morphological characteristics and type of substrate used (i.e., Vitt et al. 1997). Nevertheless, there is a clear spatial segregation between adults and subadults in relation to juveniles, mainly in the high system, as was previously suggested (Donoso-Barros 1966, Flores et al. 1977, Ortiz 1980a, Heisig 1993). Our present results clearly indicate that adults and subadults of both sexes use higher perches which are closer to the sea than do juveniles, and these latter were observed frequently in the sand, far from the sea. However, during the oviposition period (November-December) females were found using sand, as juveniles did, particularly in the low system. This switch in substrate use by females might reflect the fact that pregnant females bury their eggs in the sand (DonosoBarros 1966, Ortiz 1980a, Olivares et al. 1987).

Adults and subadults of $M$. atacamensis actively forage in the intertidal zone, and adults and subadults use perches more exposed to insolation than juveniles (Yáñez 1951). Therefore, these two age groups use areas with better thermal and trophic resources, than do juveniles. This would explain the highly territorial behavior reported at least for adult males (Heisig 1993). If food and thermal resources are limited, probably adults and subadults exhibit aggressive behavior towards juveniles; hence, juveniles with lower competitive abilities use suboptimal substrates, thus showing a spatial segregation in relation to the other age classes (Ruby \& Baird 1993). However, Donoso-Barros $(1948,1966)$ and Ortiz (1980a) proposed that this spatial segregation could be a consequence of cannibalism by adults and subadults on juveniles.
Males and females of M. atacamensis had similar body temperature during activity in the field, around $24{ }^{\circ} \mathrm{C}$. Interestingly, Heisig (1993) indicated that individuals of $M$. atacamensis are active only when the substrate temperature exceeds $22^{\circ} \mathrm{C}$. Considering that males and females did not show differences in the use of the substrate, probably they had the same availability of thermal resources, and therefore similar body temperatures are to be expected. On the other hand, body temperatures showed independence from the thermal environmental condition, since they did not correlate either with air or with substrate temperatures; therefore, this species can be considered a thermoregulator (Huey 1982, Báez \& Cortés 1990). This thermal independence, also reported for M. quadrivittatus, another species inhabiting the intertidal zones of the north of Chile (Báez \& Cortés 1990), should allow those species foraging actively in the intertidal zone or close to it, not to loose heat fast by conduction or convection. This thermal independence acquires even more relevance considering that a wet lizard will loose heat even faster than a dry one by convection (O'Connor 1999). On the other hand, in other Microlophus species it was shown that antipredator responses depend on body temperature (Watkins-Colwell 1997); thus, in the case of $M$. atacamensis, predation would be another selective factor favoring thermal independence.

Microlophus atacamensis had body temperatures significantly lower than those reported for Chilean Liolaemus lizards, which are around 35 ${ }^{\circ} \mathrm{C}$ and range from 31 to $37{ }^{\circ} \mathrm{C}$ (Fuentes \& Jaksic 1976, Marquet et al. 1989, Carothers et al. 1998, Labra 1998, Labra et al. 2001). Since there are no Liolaemus species using microhabitats similar to 
those of M. atacamensis (Donoso-Barros 1966), it is not possible to determine if this difference in body temperatures is a consequence of $M$. atacamensis being exposed to constraints for thermoregulation (Huey \& Slatkin 1976), or that there is a phylogenetic component determining this difference between genera. However, considering that the selected body temperatures (sensu Gans \& Pough 1982) of M. heterolepis are $32.4 \pm$ $1.23{ }^{\circ} \mathrm{C}$ (mean $\pm \mathrm{SE}, \mathrm{n}=6$, unpublished results), it is possible to suggest that the low body temperature of $M$. atacamensis is a consequence of constraints to thermoregulation.

In summary, $M$. atacamensis exhibts sexual size dimorphism, although this is not reflected in the type of substrate used. There is spatial segregation in the type of substrate used in adults and subadults, in relation to juveniles. Finally, males and females showed no differences in thermoregulation.

\section{ACKNOWLEDGMENTS}

Authors thank the Servicio Agrícola y Ganadero for lizard capture permit No. 3112, and to Martha Hengst, Pedro Victoriano and Fernando Torres by their invaluable assistance in the field. Hermann M. Niemeyer made important comments on an earlier version of the manuscript. Roger Sepúlveda for assintance in statistical analyses. This study was partially funded by the FONDECYT grants No. 1980115 to J.C.O. and No. 3990021 to A.L.

\section{LITERATURE CITED}

ANDERSSON M (1994) Sexual selection. Princeton University Press, Princeton, New Jersey. 599 pp.

ANDERSON R \& L VITT (1990) Sexual selection versus alternative causes of sexual dimorphism in teiid lizards. Oecologia 84: 145-157.

BÁEZ C \& A CORTÉS (1990) Precisión de la termorregulación conductual del lagarto neotropical Tropidurus quadrivittatus (Lacertilia: Iguanidae). Revista Chilena de Historia Natural 63: 203-209.

CAMILLERI C \& R SHINE (1990) Sexual dimorphism and dietary divergence: differences in trophic morphology between male and female snake. Copeia 1990: 649-658.

CAROTHERS J, P MARQUET \& F JAKSIC (1998) Thermal ecology of a Liolaemus lizard assemblage along an Andean altitudinal gradient in Chile. Revista Chilena de Historia Natural 71: 39-50.

COOPER WE Jr \& L VITT (1989) Sexual dimorphism of head and body size in an iguanid lizard: paradoxical results. American Naturalist 133: 729-735.
DARWIN C (1871) The descent of man and selection in relation to sex. Murray, London, United Kingdom. $698 \mathrm{pp}$.

DI CASTRI F (1968) Esquisse ecologique du Chili. In: Delamare-Deboutteville C \& T Rapoport (eds) Biologie de 1'Amerique austral 4: 7-52. Edition du Centre National de la Recherche Scientifique, Paris, France.

DIXON JR \& JW WRIGHT (1975) A review of the lizards of the iguanid genus Tropidurus in Peru. Contribution Science Natural History Museum (Los Angeles) 271: 1-39.

DONOSO-BARROS R (1948) Alimentación de Tropidurus peruvianus (Lesson). Boletín del Museo Nacional de Historia Natural (Chile) 24: 213-216.

DONOSO-BARROS R (1966) Los reptiles de Chile. Ediciones de la Universidad de Chile, Santiago, Chile. $458 \mathrm{pp}$.

DUARTE CF (1996) Sexual dimorphism in the sand lizard Liolaemus lutzae of southeastern Brazil. In: Péfaur JE (ed) Herpetología neotropical: 131-140. Universidad de Los Andes, Mérida, Venezuela.

DYTHAM C (1999) Choosing and using statistics: a biologist's guide. Blackwell Science, Oxford, United Kingdom. 218 pp.

FAIRBAIRN D (1990) Factors influencing sexual size dimorphism in temperate waterstriders. American Naturalist 136: 61-86.

FAIRBAIRN D (1997) Allometry for sexual size dimorphism: pattern and process in the coevolution of body size in males and females. Annual Review of Ecology and Systematics 28: 659-687.

FLORES E, M GALLARDO, X LEÓN, L LÓPEZ \& L MALDONADO (1977) Estudio preliminar de las poblaciones de Tropidurus peruvianus quadrivittatus. Tesis de Título de Profesor de Biología y Ciencias, Universidad de Chile, Iquique, Chile. xix +46 pp.

FROST D (1992) Phylogenetic analysis and taxonomy of the Tropidurus group of lizards (Iguania: Tropiduridae). American Museum Novitates 3033: 168.

FUENTES ER \& FM JAKSIC (1979) Activity temperatures of eight Liolaemus (Iguanidae) species in central Chile. Copeia 1979: 546-548.

HEISIG M (1993) An etho-ecological study of an island population of Tropidurus atacamensis. Salamandra 29: 65-81.

HUEY RB (1982) Temperature, physiology, and the ecology of reptiles. In: Gans C \& FH Pough (eds) Biology of Reptilia: 25-91. Academic Press, London, United Kingdom.

HUEY RB \& M SLATKIN (1976) Costs and benefits of lizard thermoregulation. Quarterly Review of Biology $51: 363-384$.

LABRA A (1998) Selected body temperatures of seven species of Chilean Liolaemus lizards. Revista Chilena de Historia Natural 71: 349-358.

LABRA A, M SOTO-GAMBOA \& F BOZINOVIC (2001) Behavioral and physiological thermoregulation of Atacama desert-dwelling Liolaemus lizards. Écoscience 8: 413-420. 
LOVICH JE, C ERNST \& J McBREEN (1990) Growth, maturity, and sexual dimorphism in the wood turtle, Clemmys insculpta. Canadian Journal of Zoology 68: 672-677.

LOVICH JE \& JW GIBBONS (1992) A review of techniques for quantifying sexual size dimorphism. Growth, Development and Aging 56: 269-281.

MANZUR MI \& ER FUENTES (1979) Polygyny and agonistic behavior in the tree-dwelling lizard Liolaemus tenuis (Iguanidae). Behavioral Ecology and Sociobiology 6: 23-28.

MARQUET P, JC ORTIZ, F BOZINOVIC \& FM JAKSIC (1989) Ecological aspects of thermoregulation at high altitudes: the case of Andean Liolaemus lizards in northern Chile. Oecologia 81: 16-20.

MARTINS EP (1994) Phylogenetic perspectives on the evolution of lizard territoriality. In: Vitt LJ \& ER Pianka (eds) Lizard ecology: historical and experimental perspectives: 115-144. Princeton University Press, Princeton, New Jersey.

POUGH FH \& C GANS (1982) The vocabulary of reptilian thermoregulation. In: Gans C \& FH Pough (eds) Biology of Reptilia: 17-23. Academic Press, London, United Kingdom.

O'CONNOR MP (1999) Physiological and ecological implications of a simple model of heating and cooling in reptiles. Journal of Thermal Biology 24:113-136.

OLIVARES A, L TAPIA, O GATICA, R HENRÍQUEZ \& E BUSTOS-OBREGÓN (1987) Reproductive cycle of two coastal Tropidurus lizards. Microscopía Electrónica y Biología Celular 11: 107-117.

ORTIZ JC (1980a) Estudios comparativos de algunas poblaciones de Tropidurus de la costa chilena. Anales del Museo de Historia Natural de Valparaíso (Chile) 13: 267-279.

PÉREZ-MELLADO V \& I DE LA RIVA (1993) Sexual size dimorphism and ecology: the case of a tropical lizard, Tropidurus melanopleurus (Sauria: Tropiduridae). Copeia 1993: 969-976.

RUBY DE \& DI BAIRD (1993) Effects of sex and size on agonistic encounters between juvenile and adult lizards, Sceloporus jarrovi. Journal of Herpetology 27: 100-103.

SCHOENER T (1967) The ecological significance of sexual dimorphism in size in the lizard Anolis conspersus. Science 155: 474-477.

Associate Editor: F. Bozinovic

Received September 14, 2001; accepted January 18, 2002
SCHOENER T, J SLADE \& C STINSON (1982) Diet and sexual dimorphism in the very catholic lizard genus, Leiocephalus, of the Bahamas. Oecologia 53: 160169.

SHINE R (1986) Sexual differences in morphology and niche utilization in an aquatic snake, Acrochordus arafurae. Oecologia 69: 260-267.

SHINE R (1989) Ecological causes for the evolution of sexual dimorphism: a review of the evidence. Quarterly Review of Biology 64: 419-561.

SNELL HL, DW SUGG \& E AMADOR (1988) Sexual dimorphism in size of Galapagos lava lizards: trait or consequence? American Zoologist 28: 88A.

STAMPS JA (1993) Sexual size dimorphism in species with asymptotic growth after maturity. Biological Journal of the Linnean Society 50: 123-145.

SOKAL R \& FJ ROHLF (1995) Biometry: the principles and practice of statistics in biological research. W.H. Freeman \& Company, New York, New York. 832 pp.

VITT LJ, JP CALDWELL, PA ZANI \& TA TITUS (1997) The role of habitat shift in the evolution of lizard morphology: evidence from tropical Tropidurus. Proceedings of the National Academy of Sciences USA 94: 3838-3832.

WATKINS GG (1994) Proximate causes of sexual dimorphism in the iguanid lizard Microlophus (Tropidurus) occipitalis. American Zoologist 34: 6A.

WATKINS GG (1996) Proximate causes of sexual size dimorphism in the iguanian lizard Microlophus occipitalis. Ecology 77: 1473-1482.

WATKINS GG (1997) Inter-sexual signalling and the functions of female coloration in the tropidurid lizard Microlophus occipitalis. Animal Behaviour 53: 843852.

WATKINS GG (1998) Function of a secondary sexual ornament: the crest in the South American iguanian lizard Microlophus occipitalis (Peters, Tropiduridae). Herpetologica 54: 161-169.

WATKINS-COLWELL G (1997) Approach distance in Galapagos lava lizards (Microlophus (= Tropidurus), Tropiduridae). Bulletin of the Maryland Herpetological Society 33: 118-125.

YÁÑEZ P (1951) Vertebrados marinos chilenos. Revista de Biología Marina (Chile) 3: 1-18.

ZAR J (1996) Biostatistical analysis. Third edition. Prentice-Hall, Upper Saddle River, New Jersey. 918 pp. 


\section{APPENDIX 1}

List of the individuals of Microlophus atacamensis with their geographic coordinates, used in this study and deposited in the herpetological collection of the Museo de Zoología of Universidad de Concepción (MZUC):

Lista de los individuos de Microlophus atacamensis con sus distribuciones geográficas, utilizados en este estudio y depositados en la colección herpetológica del Museo de Zoología de la Universidad de Concepción (MZUC):

Desembocadura Río Loa (sur) II Región, (25²5’ S, 70²7’ W) MZUC 26165-167; Isla Santa María, Antofagasta, II Región (2326' S, 70³7' W) MZUC 26168-194; Coloso, Playa Rocosa and Jardín la Escondida, Antofagasta, II Región (23ํ5' S, 70²7' W) MZUC 26152-164, MZUC 26195-202, 35 km N Tal-Tal, II Región (2505' S, 70³0' W) MZUC 26127-133, 17 km N Tal-Tal, II Región (2514' S, 70²7’ W) MZUC 26124-126; Tres Playitas, Huasco, III Región (28²9’ S, 71º 17’ W) MZUC 26209224. 